\title{
Pelaksanaan Kegiatan Supervisi Kunjungan Kelas Sebagai Upaya Meningkatkan Kemampuan Guru Dalam Penilaian Hasil Belajar Siswa Di SMK Negeri 1 Sutera
}

\author{
Lili Suryati ${ }^{1^{*}}$ \\ ${ }^{1}$ Teknik Audio Video, SMK Negeri 1 Sutera \\ *e-mail: lilisuryati4@gmail.com \\ (Diajukan:29 Januari 2021, direvisi: 16 Februari 2021, disetujui:17 Februari 2021)
}

\begin{abstract}
Abstrak
Permasalahan yang peneliti temukan di lapangan yaitu hasil evaluasi pelaksanaan kegiatan pembelajaran menunjukkan bahwa penilaian yang dilakukan guru di kelas kurang mampu memperlihatkan tuntutan hasil belajar siswa, oleh sebab itu tujuan penelitian ini yaitu untuk meningkatkan peran serta kepala SMK Negeri 1 Sutera dalam memfasilitasi para guru yang dihadapkan dengan kesulitan teknis pengelolaan pembelajaran, yang akan memberi dampak kurang baik terhadap proses dan hasil belajar siswa. Subjek penelitian adalah guru kelas di SMK Negeri 1 Sutera yang terdiri dari 6 orang guru kelas X s.d guru kelas XII. Sedangkan yang menjadi objek penelitian adalah peningkatan kemampuan guru dalam melakukan kegiatan penilaian hasil belajar siswa Data yang dikumpulkan dalam pelaksanaan kegiatan penelitian tindakan kelas ini melalui beberapa teknik, yaitu teknik observasi, teknik wawancara dan teknik dokumentasi. Hasil penelitian menunjukkan bahwa bahwa pelaksanaan supervisi kunjungan kelas terbukti dapat meningkatkan kemampuan guru dalam melaksanakan kegiatan penilaian hasil belajar. Guru menunjukkan keseriusan dalam memahami dan melaksanakan kegiatan penilaian hasil belajar. Hal itu dapat dibuktikan dari hasil observasi/pengamatan yang memperlihatkan bahwa terjadi peningkatan kemampuan guru melaksanakan kegiatan penilaian hasil belajar dari siklus ke siklus . Pada siklus I nilai rata-rata capaian secara klasikal dari 42,82 dengan kategori kurang, meningkat menjadi 67,82 dengan kategori cukup serta pada siklus terakhir menjadi 86,11 dengan kategori baik, dan secara individual per guru dari 2 orang atau 33,33\% pada siklus pertama meningkat menjadi $100 \%$ atau 6 orang guru pada siklus terakhir.
\end{abstract}

Kata Kunci: kunjungan kelas, penilaian, hasil belajar.

Abstract
The problem that the researchers found in the field was that the results of the evaluation of
the implementation of learning activities showed that the assessment carried out by the
teacher in the classroom was less able to show the demands of student learning outcomes,
therefore the aim of this study was to increase the participation of the principal of SMK
Negeri 1 Sutera in facilitating the teachers who were faced with with the technical
difficulties of managing learning, which will have a negative impact on the process and
student learning outcomes. The research subjects were class teachers at SMK Negeri 1
Sutera which consisted of 6 class X teachers to class XII teachers. Meanwhile, the object of
research is the improvement of the teacher's ability to assess student learning outcomes.
Base collected in the implementation of this classroom action research activity through
several techniques, namely observation techniques, interview techniques and documentation
techniques. The results showed that the implementation of classroom visit supervision was
proven to improve the ability of teachers to carry out learning outcome assessment

This is an open access article distributed under the Creative Commons 4.0 Attribution License 
activities. The teacher shows seriousness in understanding and carrying out learning outcome assessment activities. This can be proven from the results of observations / observations which show that there is an increase in the ability of teachers to carry out assessment activities of learning outcomes from cycle to cycle. In the first cycle the classical average value of achievement from 42.82 in the poor category, increased to 67.82 in the sufficient category and in the last cycle to 86.11 in the good category, and individually per teacher from 2 people or $33.33 \%$ in the first cycle increased to $100 \%$ or 6 teachers in the last cycle

Keywords: classroom visits, assessment, learning outcomes. 


\section{PENDAHULUAN}

Penilaian dan kegiatan pembelajaran bermuara pada penguasaan kompetensi yang diharapkan. Selama ini pelaksanaan penilaian di kelas kurang mampu menggambarkan kemampuan siswa yang beragam karena cara dan alat yang digunakan kurang sesuai dan kurang bervariasi. Karena keterbatasan kemampuan dan waktu, penilaian cenderung dilakukan dengan menggunakan cara dan alat yang lebih menyederhanakan tuntutan perolehan siswa. Berkaitan dengan tugas kepala sekolah sebagai administrator sekolah, pemimpin pengajaran, dan supervisor [1]. Sebagai administrator bertugas mendayagunakan sumber daya yang tersedia meliputi pengelolaan pengajaran, pengelolaan kesiswaan, pengelolaan personel, pengelolaan sarana, pengelolaan keuangan, pengelolaan hubungan sekolah dan masyarakat. Sebagai pemimpin pengajaran harus mampu menggerakkan potensi personel sekolah meliputi kegiatan pengembangan staf dan guru, melaksanakan program evaluasi terhadap guru dan staf. Sebagai supervisor memunyai tugas memberikan bantuan teknis profesional pada guruguru dalam merencanakan, melaksanakan dan mengevaluasi pengajaran agar tujuan pembelajaran dapat dicapai secara maksimal. Dalam menjalankan tugas sebagai supervisor, kepala sekolah dapat memilih pendekatan yang tepat sesuai dengan masalah yang dihadapi guru dan perlu memperhatikan tingkat kematangan guru. Supervisi tidak didefinisikan secara sempit sebagai satu cara terbaik untuk diterapkan disegala situasi melainkan perlu memperhatikan kemampuan individu, kebutuhan, minat, tingkat kematangan individu, karakteristik personal guru, semua itu dipertimbangkan untuk menerapkan supervisi.

Hasil evaluasi pelaksanaan kegiatan pembelajaran menunjukkan bahwa penilaian yang dilakukan di kelas kurang mampu memperlihatkan tuntutan hasil belajar siswa, yaitu mengungkapkan pemahamannya dengan kalimat sendiri secara lisan dan tertulis, mengekspresi gagasan, khususnya dalam bentuk gambar, grafik, diagram, atau simbol lainnya, mengembangkan keterampilan fungsional sebagai hasil interaksi dengan lingkungan fisik, sosial, dan budaya, menggunakan lingkungan (fisik, sosial, dan budaya) sebagai sumberdan media belajar, membuat laporan penelitian dan membuat sinopsis; dan mengembangkan kemampuan bereksporasi dan mengaktualisasi diri. Disamping itu, penilaian dilakukan tidak hanya untuk mengungkapkan hasil belajar ranah kognitif, tetapi juga diharapkan mampu mengungkapkan hasil belajar siswa dalam lingkup ranah afektif dan psikomotor. Diharapkan penilaian kelas mampu mengatasi permasalahan penilaian yang ada sehingga hasil belajar siswa dapat dinilai sesuai dengan tuntutan kompetensi.

\section{A. Penilaian (Assessment)/ Hasil Belajar}

Pada kegiatan pembelajaran seorang guru harus menguasai beberapa pengetahuan terkait dengan penilaian pendidikan. Diantaranya; (1) mampu memilih prosedurprosedur penilaian yang tepat untuk membuat keputusan pembelajaran, (2) mampu mengembangkan prosedur penilaian yang tepat untuk membuat keputusan pembelajaran, (3) mampu dalam melaksanakan, melakukan penskoran, serta 
menafsirkan hasil penilaian yang telah dibuat, (4) mampu menggunakan hasil-hasil penilaian untuk membuat keputusan-keputusan di bidang pendidikan, (5) mampu mengembangkan prosedur penilaian yang valid dan menggunakan informasi penilaian, dan (6) mampu dalam mengkomunikasikan hasilhasil penilaian [2].

Penilaian merupakan proses sistematis yang menunjukan sejauh mana tujuan instruksional tercapai[3]. Penilaian juga merupakan suatu proses dalam mengumpulkan informasi dan membuat keputusan berdasarkan informasi tersebut. Penilaian merupakan suatu proses atau kegiatan yang sistematis dan berkesinambungan untuk mengumpulkan informasi tentang proses dan hasil belajar peserta didik dalam rangka membuat keputusan-keputusan berdasarkan kriteria dan pertimbanagan tertentu [4]. Definisi dari penilaian juga disampaikan oleh Ralph Tyler yang mengungkapkan bahwa penilaian merupakan sebuah proses pengumpulan data untuk menentukan sejauh mana, dalam hal apa, dan bagaimana tujuan pendidikan sudah tercapai. Pendapat lain mengatakan bahwa penilaian (assessment) merupakan istilah yang mencakup semua metode yang biasa dipakai untuk mengetahui keberhasilan belajar siswa dengan cara menilai unjuk kerja individu peserta didik atau kelompok [5].

Berdasarkan beberapa pendapat yang disampaikan, maka dapat disimpulkan bahwa penilaian adalah suatu proses pengumpulan informasi secara menyeluruh yang dilakukan secara terus menerus untuk mengetahui kemampuan atau keberhasilan siswa dalam pembelajaran dengan menilai kinerja siswa baik kinerja secara individu maupun dalam kegiatan kelompok. Penilaian itu harus mendapatkan perhatian yang lebih dari seorang guru. Dengan demikian, penilaian tersebut harus dilaksanakan dengan baik, karena penilaian merupakan komponen vital (utama) dari pengembangan diri yang sehat, baik bagi individu (siswa) maupun bagi organisasi/kelompok.

\section{B. Supervisi Kunjungan Kelas}

Supervisi secara etimologi berasal dari kata "super" dan "visi" yang mengandung arti melihat dan meninjau dari atas atau menilik dan menilai dari atas yang dilakukan oleh pihak atasan terhadap aktivitas, kreativitas, dan kinerja bawahan [6]. Supervisi pengajaran juga merupakan segala sesuatu yang dilakukan kepala sekolah dengan cara yang langsung mempengaruhi proses belajar mengajar dalam usaha meningkatkan proses belajar siswa [7]. Pendapat lain mengatakan bahwa supervisi ialah suatu aktivitas pembinaan yang direncanakan untuk membantu para guru dan pegawai sekolah lainnya dalam melakukan pekerjaan mereka secara efektif [8]. Sedangkan peneliti lain juga mengungkapkan supervisi pengajaran dengan menyebut sebagai "Supervisi Klinis" yaitu suatu bentuk supervisi yang difokuskan pada peningkatan kualitas mengajar melalui sarana siklus yang simpatik untuk langkah-langkah intensif dan cermat tentang penampilan mengajar yang nyata serta bertujuan untuk mengadakan perubahan dengan cara yang rasional [9]. Berdasarkan pengertian tersebut di atas dapat disimpulkan bahwa supervisi pengajaran adalah upaya kepala sekolah dalam pembinaan guru agar guru dapat meningkatkan kualitas mengajarnya dengan melalui langkah-langkah 
perencanaan, penampilan mengajar yang nyata serta mengadakan perubahan dengan cara yang rasional dalam usaha meningkatkan hasil belajar siswa.

Supervisi kunjungan kelas merupakan salah satu pendekatan supervisi individual. Supervisi kunjungan kelas adalah kegiatan kepala sekolah/pengawas sekolah mengunjungi kelas tempat guru sedang melaksanakan pembelajaran [10]. Kepala sekolah maupun pengawas dalam melaksanakan supervisi kepada guru di kelas dilengkapi dengan lembar observasi/kuesioner yang dijadikan alat ukur keberhasilan guru dalam membelajarkansiswa. Pendapat yang hampir sama juga dikemukakan bahwa supervisi kunjungan kelas adalah pengamatan yang dilakukan oleh kepala sekolah atau pengawas terhadap guru yang sedang mengajar dan melihat alat, metode, dan sarana belajar lainnya di kelas [11]. Sedangkan teknik kunjungan kelas (classroom visitation) merupakan kunjungan sewaktu-waktu yang dilakukan oleh seorang supervisor (kepala sekolah, penilik atau pengawas) untuk melihat atau mengamati seorang guru yang sedang mengajar di kelas [8]. Tujuannya adalah untuk mengobservasi bagaimana seorang guru mengajar di kelas, apakah sudah memenuhi syarat-syarat didaktis atau metodik yang sesuai. Seorang pengawas atau kepala sekolah datang ke dalam kelas di mana guru sedang mengajar. Pengawas atau kepala sekolah mengadakan pembinaan terhadap suasana belajara mengajar di kelas. Tujuan kunjungan kelas adalah dalam rangka menolong guru dalam upaya untuk memecahkan berbagai masalah mengajar yang dihadapi oleh guru. Dalam kunjungan kelas yang diutamakan adalah mempelajari kesulitan anak dalam belajar, bagaimana masalah yang dihadapi oleh guru dalam mengajar. Sedangkan fungsi dari kunjungan kelas adalah untuk meningkatkan cara mengajar guru dan belajar murid atau untuk mengenalkan model pembelajaran yang baru bagi guru [12]. Kunjungan kelas juga membantu guru dalam meneliti prinsipprinsip dalam pengelolaan pelaksanaan pmbelajaran.

Berdasarkan teknik supervisi kunjungan kelas yang sudah dijelaskan dapat diketahui bahwa teknik kunjungan kelas merupakan suatu pembinaan yang dilakukan oleh kepala sekolah untuk dapat mengamati secara langsung proses pembelajaran di kelas. Tujuannya adalah untuk menolong guru dalam mengatasi masalah di kelas. Diatara beberapa cara melaksanakan kunjungan kelas dan tahap pelaksanaan supervise dapat dijelaskan [13]. Diantara cara melakukan kunjungan kelas adalah (1) dengan pemberitahuan atau tanpa adanya pemberitahuan terlebih dahulu tergantung sifat tujuan dan masalahnya, (2) atas permintaan sendiri dari guru yang bersangkutan, (3) sudah memiliki instrumen atau catatan-catatan, dan (4) tujuan kunjungan harus jelas. Sedangkan tahapan pelaksanaan supervisi kunjungan kelas adalah (1) tahap persiapan dimana supervisor merencanakan waktu, sasaran, dan tata cara dalam mengobservasi guru selama kunjungan kelas, (2) tahap pengamatan pelaksanaan supervisi kunjungan kelas (pada tahap ini, supervisor mengamati jalannya proses pembelajaran berlangsung), (3) supervisor bersama guru mengadakan perjanjian untuk membicarakan akan hasihasil observasi, dan (4) tahap terakhir adalah tahap tindak lanjut dari kegiatan supervisi.

\section{METODE}


Penelitian ini tergolong Penelitian Tindakan Sekolah (PTS) dengan empat langkah pokok, diantaranya perencanaan tindakan, pelaksanaan tindakan, pengamatan (observasi), dan refleksi, dengan melibatkan enam orang guru SMK Negeri 1 Sutera. Penelitian Tindakan Sekolah ini dilaksanakan di SMK Negeri 1 Sutera Kecamatan Sutera Kabupaten Pesisir Selatan. Penelitian dilaksanakan tahun pelajaran 2020/ 2021 selama 4 bulan, dimulai dari bulan Juli 2020 sampai dengan bulan Oktober 2020. Objek penelitian ini adalah guru SMK Negeri 1 Sutera yang berjumlah 6 orang.

Subjek penelitian adalah guru Mata Pelajaran Kelompok A (Muatan Nasional), Mata Pelajaran Kelompok B (Muatan Kewiayahan), Mata Pelajaran Kelompok C1 (Dasar Bidang Keahlian), Mata Pelajaran Kelompok C2 (Dasar Program Keahlian), Mata Pelajaran Kelompok C3 (Kompetensi Keahliah) dan Guru Bimbingan Konseling (BK) di SMK Negeri 1 Sutera. Sedangkan yang menjadi objek penelitian adalah peningkatan kemampuan guru dalam melaksanakan kegiatan penilaian hasil belajar. Teknik pengumpulan data dalam penelitian ini adalah observasi, dan dokumentasi. Alat pengumpulan data pada PTS adalah observasi dan dokumentasi. Observasi menggunakan lembar observasi untuk mengetahui peningkatan kemampuan masingmasing guru dalam pengelolaan pembelajaran Sedangkan dokumentasi untuk mencari data atau variabel yang berupa catatan, transkip, buku, surat kabar, majalah, foto dan sebagainya.

Analisis data dapat dilakukan melalui tiga tahap yaitu mereduksi data, mendeskripsikan data dan membuat kesimpulan. Mereduksi data merupakan kegiatan menyeleksi data sesuai dengan fokus permasalahan. Pada tahap ini peneliti mengumpulkan semua instrumen yang digunakan untuk mengumpulkan data untuk dikelompokkan sesuai masalah. Hal ini juga memungkinkan peneliti untuk membuang data yang tidak diperlukan. Mendeskripsikan data dilakukan agar data yang telah diorganisir menjadi bermakna. Bentuk deskripsi tersebut dapat berupa naratif, grafik atau dalam bentuk tabel. Tahap terakhir adalah membuat kesimpulan dari data yang telah dideskripsikan. Analisis data dalam penelitian ini menggunakan teknik analisis deskriptif kualitatif serta kuantitatif. Indikator kinerja yang ditetapkan adalah meningkatkan kemampuan guru dalam melakukan kegiatan penilaian hasil belajar siswa melalui kegiatan supervisi kunjungan kelas di SMK Negeri 1 Sutera. Guru dinyatakan meningkat kemampuannya dalam melakukan kegiatan penilaian hasil belajar apabila secara individual memenuhi rentang 76-100 atau masuk kategori baik, dan secara klasikal apabila minimal $85 \%$ guru termasuk dalam kategori Baik.

\section{HASIL DAN PEMBAHASAN}

Hasil observasi yang dilakukan dengan kegiatan supervisi kunjungan kelas terhadap enam orang guru, peneliti memperoleh informasi bahwa semua guru (enam orang) dinyatakan belum mampu melaksanakan kegiatan penilaian hasil belajar siswa dengan baik dan benar. Hasil observasi pada kondisi awal sebagaimana dijelaskan pada tabel 1. Berdasarkan penjelasan tabel 1 dapat dijabarkan bahwa pada kondisi awal, 6 orang guru atau $100 \%$ dinyatakan belum mampu melaksanakan penilaian hasil belajar 
dengan benar. Secara klasikal peningkatan kemampuan guru dalam melaksanakan kegiatan penilaian hasil belajar belum memenuhi kriteria keberhasilan karena baru memperoleh angka 42,82 dengan kriteria kurang. Hal ini menunjukkan bahwa perolehan hasil tersebut masih berada di bawah kriteria keberhasilan yaitu minimal mendapat skor 76 atau lebih dengan kriteria minimal baik.

Tabel 1. Rekapitulasi Peningkatan Kemampuan Guru dalam Melaksanakan Kegiatan Penilaian Hasil Belajar Siswa pada Kondisi Awal

\begin{tabular}{cccc}
\hline No & Nama Guru & Persentase Capaian & Kriteria Hasil \\
\hline 1 & Mapel Kelompok A & 37,50 & $\mathrm{~K}$ \\
2 & Mapel Kelompok B & 33,33 & $\mathrm{~K}$ \\
3 & Mapel Kelompok C1 & 41,67 & $\mathrm{~K}$ \\
4 & Mapel Kelompok C2 & 43,06 & $\mathrm{~K}$ \\
5 & Mapel Kelompok C3 & 44,44 & $\mathrm{~K}$ \\
6 & Guru BK & 56,94 & $\mathrm{C}$ \\
\hline & Rata-rata & 42,82 & $\mathrm{~K}$ \\
\hline
\end{tabular}

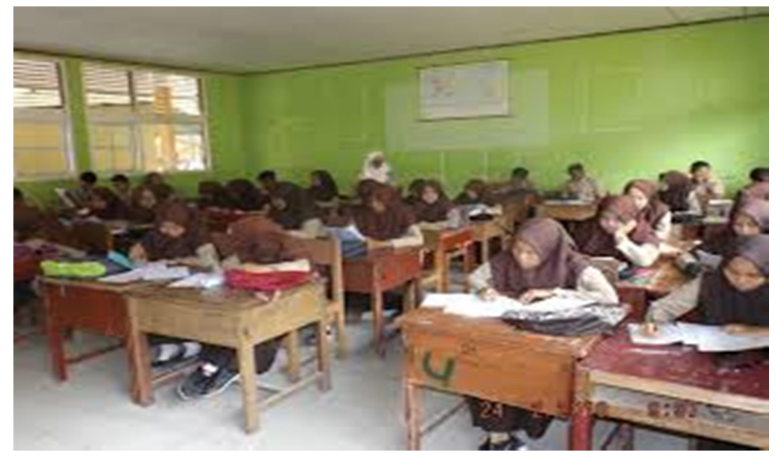

Gambar 1. Kegiatan Penilaian Hasil Belajar Siswa pada Kondisi Awal

Proses pelaksanaan siklus I menempuh empat tahapan, yakni: (1) perencanaan, (2) pelaksanaan, (3) observasi, dan (4) refleksi. Observasi dilakukan oleh penulis sejak awal hingga akhir kegiatan pembelajaran dilaksanakan oleh guru dan siswa. Berdasarkan hasil observasi diperoleh beberapa catatan serta hasil penilaian terhadap kemampuan masing-masing guru, hasil catatan dan penilaian pada siklus I dapat dilihat pada table 2 .

Tabel 2. Rekapitulasi Peningkatan Kemampuan Guru dalam Melaksanakan Kegiatan Penilaian Hasil Belajar Siswa pada Siklus Pertama

\begin{tabular}{cccc}
\hline No & Nama Guru & Persentase Capaian & Kriteria Hasil \\
\hline 1 & Mapel Kelompok A & 63,89 & $\mathrm{C}$ \\
2 & Mapel Kelompok B & 76,39 & $\mathrm{~B}$ \\
3 & Mapel Kelompok C1 & 63,89 & $\mathrm{C}$ \\
4 & Mapel Kelompok C2 & 61,11 & $\mathrm{C}$ \\
5 & Mapel Kelompok C3 & 62,50 & $\mathrm{C}$ \\
6 & Guru BK & 79,17 & $\mathrm{~B}$ \\
\hline & Rata-rata & 67,82 & $\mathrm{C}$ \\
\hline
\end{tabular}


Berdasarkan penjelasan tabel 2 di atas dapat dijabarkan bahwa pada pelaksanaan siklus pertama, ada dua orang guru atau 33,33\% yang sudah mampu melaksanakan penilaian hasil belajar dengan benar, sedangkan 4 orang lainnya atau $66,67 \%$ dinyatakan belum mampu melaksanakan penilaian hasil belajar dengan benar. Secara klasikal peningkatan kemampuan guru dalam melaksanakan kegiatan penilaian hasil belajar belum memenuhi kriteria keberhasilan, karena baru memperoleh angka 67,82 dengan kriteria Cukup. Hal ini menunjukkan bahwa perolehan hasil tersebut masih berada di bawah kriteria keberhasilan yaitu minimal mendapat skor 76 atau lebih dengan kriteria minimal Baik

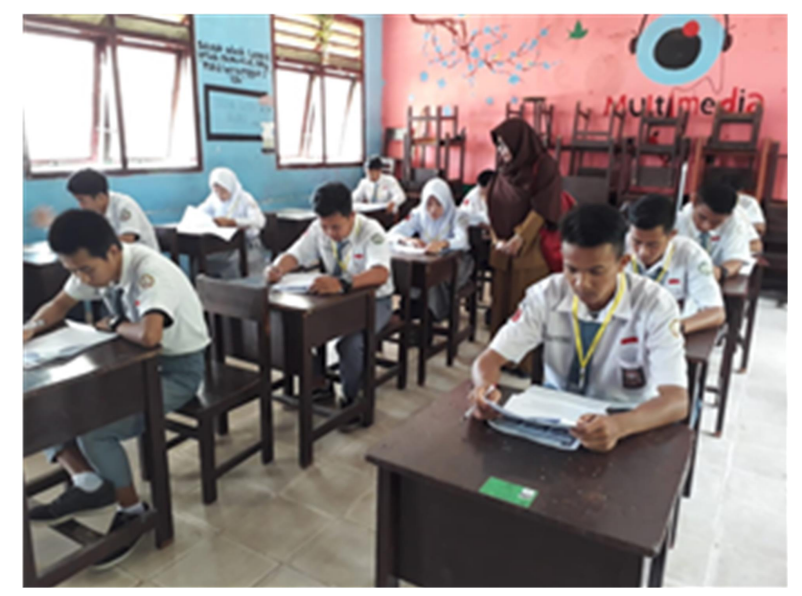

Gambar 2. Kegiatan Penilaian Hasil Belajar Siswa pada Siklus I

Merefleksi hasil pelaksanaan tindakan siklus I, penulis beserta guru-guru melaksanakan diskusi. Melalui upaya ini diperoleh suatu kesepakatan mengenai keberhasilan dan kegagalan siklus I serta upaya untuk mengatasi agar tidak timbul kegagalan pada hal yang sama di siklus II. Untuk mempertahankan dan meningkatkan keberhasilan siklus I, maka pada siklus II direncanakan tindakan sebagai berikut.

a. Peneliti sebagai kepala sekolah yang bertugas menjadi supervisor harus berusaha meningkatkan pemahaman guru SMK Negeri 1 Sutera baik dalam mengelola administrasi perencanaan pembelajaran, pelaksanaan pembelajaran, evaluasi pembelajaran, maupun upaya menindaklanjuti hasil pembelajaran.

b. Pada saat proses pembelajaran sedang berlangsung, mulai dari menyusun rencana pembelajaran, melaksanakan pembelajaran, mengevaluasi, dan menindaklanjuti hasilnya, peneliti sebagai kepala sekolah yang bertugas sebagai supervisor harus selalu mendampingi para guru, agar tidak terjadi lagi hal-hal yang diharapkan seperti pada siklus I. Tentunya untuk itu perlu ada waktu. Oleh karena itu, satu minggu sebelum pelaksanaan siklus II akan digunakan untuk proses pembinaan, yang dilakukan setelah jam pelajaran efektif berlangsung. Atas dasar itu, kepada semua guru, penulis memohon kesediaannya agar tidak lantas meninggalkan sekolah. Waktu yang diperlukan untuk itu lebih kurang 2 jam. Hal ini telah disepakati oleh para guru. 
Proses pelaksanaan siklus I, pada siklus II pun menempuh beberapa tahapan berikut: (1) perencanaan, (2) pelaksanaan, (3) observasi, dan (4) refleksi. Untuk menggambarkan aktivitas pelaksana tindakan dan subjek, serta aktivitas pengamat untuk mendapatkan data yang diharapkan. Observasi dilakukan oleh penulis sejak awal hingga akhir kegiatan pembelajaran dilaksanakan oleh guru dan siswa. Berdasarkan hasil observasi diperoleh beberapa catatan serta hasil penilaian terhadap kemampuan masing-masing guru seperti pada tabel 3 .

Tabel 3 Rekapitulasi Peningkatan Kemampuan Guru dalam Melaksanakan Kegiatan Penilaian Hasil Belajar Siswa pada Siklus Kedua

\begin{tabular}{cccc}
\hline No & Nama Guru & Persentase Capaian & Kriteria Hasil \\
\hline 1 & Mapel Kelompok A & 87,50 & B \\
2 & Mapel Kelompok B & 84,72 & B \\
3 & Mapel Kelompok C1 & 86,11 & B \\
4 & Mapel Kelompok C2 & 84,72 & B \\
5 & Mapel Kelompok C3 & 86,11 & B \\
6 & Guru BK & 87,50 & B \\
\hline
\end{tabular}

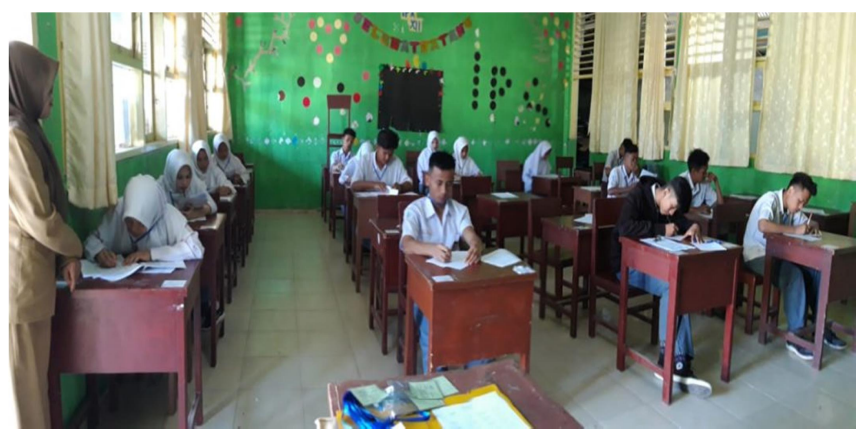

Gambar 3. Kegiatan Penilaian Hasil Belajar Siswa pada siklus II

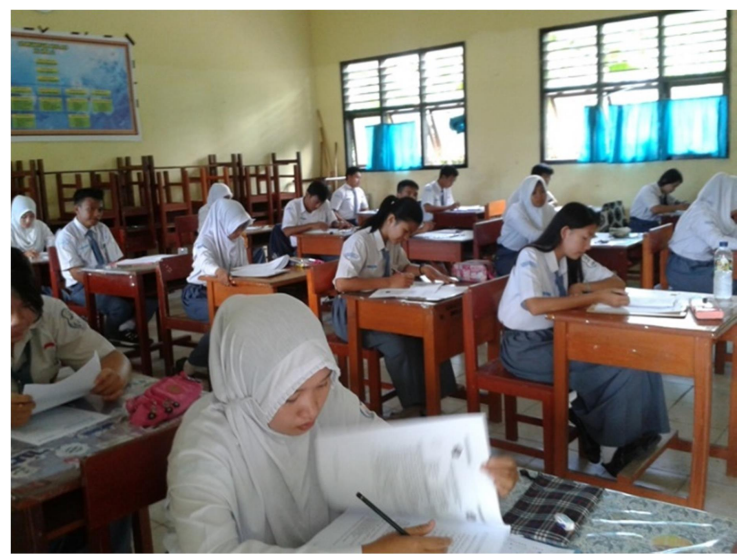

Gambar 4. Kegiatan Penilaian Hasil Belajar Siswa pada siklus II

Berdasarkan penjelasan tabel 3 di atas dapat dijabarkan bahwa pada pelaksanaan siklus kedua, semua guru dinyatakan telah mampu melaksanakan penilaian hasil belajar 
dengan benar. Secara klasikal peningkatan kemampuan guru dalam melaksanakan kegiatan penilaian hasil belajar telah memenuhi kriteria keberhasilan, karena baru memperoleh angka 86,11 dengan kriteria baik. Hal ini menunjukkan bahwa perolehan hasil tersebut sudah berada di atas kriteria keberhasilan yaitu minimal mendapat skor 76 atau lebih dengan kriteria minimal baik. Berdasarkan perkembangan perilaku-perilaku baik seperti di atas, maka terjadilah suatu perubahan ke arah yang dinginkan oleh masing-masing. Meski untuk berubah itu beresiko, baik kepala sekolah maupun guruguru SMK Negeri 1 Sutera tetap mengambil strategi ini. Ketimbang tidak berubah sama sekali, mereka merasa yakin jauh akan lebih beresiko. Kepiawaian kepala sekolah dalam memilih tingkat resiko, baik secara ekonomis maupun material, dapat mencegah hal-hal yang tidak diinginkan, seperti pemborosan, lebih meluangkan waktu, tenaga, dan pemikiran. Termasuk masalah yang kompleks dan tidak mudah dalam menyelesaikan kasus pengelolaan proses pembelajaran. Terlebih lagi ketika masalah itu berkaitan dengan kualitas pengelolaan proses pembelajaran. Sudah menjadi rumus yang baku untuk bisa berlangsungnya hal itu diperlukan segala sesuatunya yang berkualitas, baik SDM guru, material, maupun proses berlangsungnya. Oleh karena itu peran serta kepala sekolah akan sangat mewarnai peran serta guru dan siswa. Supervisi merupakan bagian integral dari kemampuan profesional kepala sekolah yang berkualitas. Tanpa berkemampuan melakukan supervisi, mustahil kepala sekolah SMK Negeri 1 Sutera berhasil meningkatkan kualitas kemampuan guru dalam melaksanakan kegiatan penilaian hasil belajar. Secara kuantitas, peningkatan kemampuan guru dalam melaksanakan penilaian hasil belajar berdasarkan rata-rata capaian nilai pada setiap siklusnya dapat dilihat pada tabel 4 .

Tabel 4. Rekapitulasi Peningkatan Kemampuan Guru dalam Melaksanakan Kegiatan Penilaian Hasil Belajar Siswa Berdasarkan Rata-rara Capain Nilai pada Kondisi Awal,

Siklus Pertama dan Kedua

\begin{tabular}{cccc}
\hline No & Siklus & Rata-Rata Capaian Nilai & Kriteria \\
\hline 1 & Awal & 42,82 & K \\
2 & Siklus I & 67,82 & C \\
3 & Siklus II & 86,11 & B \\
\hline
\end{tabular}

Pada siklus I nilai rata-rata capaian secara klasikal dari 42,82 dengan kategori kurang, meningkat menjadi 67,82 dengan kategori cukup serta pada siklus terakhir menjadi 86,11 dengan kategori Baik, dan secara individual per guru dari 2 orang atau $33,33 \%$ pada siklus pertama meningkat menjadi $100 \%$ atau 6 orang guru pada siklus terakhir. 
Tabel 5. Rekapitulasi Peningkatan Kemampuan Guru dalam Melaksanakan Kegiatan Penilaian Hasil Belajar Siswa Berdasarkan Ketuntasan Guru Per Individu pada Kondisi Awal, Siklus Pertama dan Kedua

\begin{tabular}{cccccc}
\hline \multirow{2}{*}{ No } & \multirow{2}{*}{ Siklus } & \multicolumn{5}{c}{ Ketuntasan } \\
\cline { 3 - 6 } & & Tuntas & $\%$ & Belum & $\%$ \\
\hline 1 & Awal & 0 & 0,00 & 5 & 100 \\
2 & Siklus I & 2 & 33,33 & 4 & 66,67 \\
3 & Siklus II & 6 & 100,00 & 0 & 0,00 \\
\hline
\end{tabular}

Berdasarkan paparan di atas menunjukkan bahwa pelaksanaan supervisi kepala sekolah dengan pelaksanaan kunjungan kelas terbukti dapat meningkatkan kemampuan guru dalam melaksanakan kegiatan penilaian hasil belajar siswa bagi guru-guru di SMK Negeri 1 Sutera. Hal ini sesuai dengan pengertian supervisi kunjungan kelas merupakan salah satu pendekatan supervisi individual dimana kepala sekolah/pengawas sekolah mengunjungi kelas tempat guru sedang melaksanakan pembelajaran. Kepala sekolah maupun pengawas dalam melaksanakan supervisi kepada guru di kelas dilengkapi dengan lembar observasi/kuesioner yang dijadikan alat ukur keberhasilan guru dalam membelajarkan siswa. Berdasarkan hasil penelitian telah memenuhi tujuan supervisi yang mana tujuan supervisi adalah mengembangkan iklim yang kondusif dan lebih baik dalam kegiatan pembelajaran, melalui pembinaan dan peningkatan profesi mengajar.

\section{KESIMPULAN DAN SARAN}

Berdasarkan hasil Penelitian Tindakan Sekolah (PTS) dapat disimpulkan bahwa pelaksanaan supervisi kunjungan kelas terbukti dapat meningkatkan kemampuan guru dalam melaksanakan kegiatan penilaian hasil belajar. Guru menunjukkan keseriusan dalam memahami dan melaksanakan kegiatan penilaian hasil belajar. Hal itu dapat dibuktikan dari hasil observasi/pengamatan yang memperlihatkan bahwa terjadi peningkatan kemampuan guru melaksanakan kegiatan penilaian hasil belajar dari siklus ke siklus . Pada siklus I nilai rata-rata capaian secara klasikal dari 42,82 dengan kategori kurang, meningkat menjadi 67,82 dengan kategori cukup serta pada siklus terakhir menjadi 86,11 dengan kategori BAIK, dan secara individual per guru dari 2 orang atau $33,33 \%$ pada siklus pertama meningkat menjadi $100 \%$ atau 6 orang guru pada siklus terakhir.

\section{REFERENSI}

[1] N. S, Metode Research (Penelitian Ilmiah). Jakarta: Bumi Aksara, 2005.

[2] Kusaeri and Suprananto, "Pengukuran dan Penilaian Pendidikan," Buku Graha Ilmu, vol. 1, no. 1, pp. 1-10, 2012, [Online]. Available: info@grahailmu.co.id.

[3] M. Ngalim Purwanto, Prinsip-prinsip dan teknik evaluasi pengajaran. Jakarta: Remaja Rosdakarya, 1994.

[4] Z. Arifin and H. Retnawati, "Analisis Instrumen Pengukur Higher Order Thinking 
Skills ( HOTS ) Matematika Siswa SMA,” Semin. Nas. Mat. Dan Pendidik. Mat. Uny, no. 20, pp. 783-790, 2015.

[5] Mimin Haryati, Model dan teknik penilaian pada tingkat satuan pendidikan. Jakarta: GP Press, 2008.

[6] E. Mulyasa, Manajemen Berbasis Sekolah: Konsep, Strategi, dan Implementasi. Bandung: Rosdakarya, 2004.

[7] Piet A. Sahertian, Konsep Dasar \& Teknik Supervisi Pendidikan. Jakarta: Rineka Cipta, 2008.

[8] M. Ngalim Purwanto, Administrasi dan Supervisi Pendidikan. Jakarta: Remaja Rosdakarya, 1987.

[9] Suharsimi Arikunto, Organisasi dan Administrasi Pendidikan Teknologi dan Kejuruan. Jakarta: Rajawali Pers, 1989.

[10] F. M. Piet A. Sahertian, Prinsip dan tehnik supervisi pendidikan. Surabaya: Usaha Nasional, 1981.

[11] W. Sanjaya, Strategi Pembelajaran Berbasis Standar Proses Pendidikan. Jakarta: Kencana Prenada Media, 2006.

[12] Nyoman Dantes, Metodelogi Penelitian. Yogyakarta: CV Andi Offset, 2012.

[13] Dirjen PMPTK, Penulisan Mudul. Jakarta: Dirjen PMPTK, 2008. 